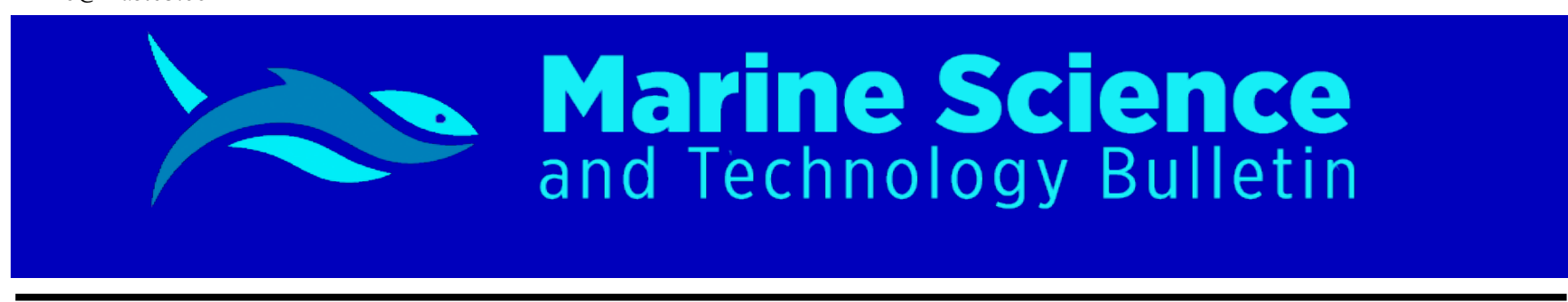

RESEARCH ARTICLE

\title{
Determination of Fish Consuming Habits of Vocational School Students from Different Families
}

\author{
Gökhan Arslan ${ }^{1^{*}}$ \\ ${ }^{1}$ Atatürk University, Fisheries Faculty, Erzurum, Turkey
}

\begin{abstract}
Article History:
Received: 19.09.2019

Received in revised form: 30.10.2019

Accepted: 30.10.2019

Available online: 03.11.2019

Keywords:

Fish consumption

Consumer preference

Erzurum

Narman

\section{ARTICLE INFO}

A B S T RA C T

In this study, the fish consuming habits of the university students of Narman Vocational School of Atatürk University in Erzurum city were studied. The data was determined by face-to-face questions asked to the 269 participants and then subjected to statistical analyses by using Chi-square independence test. The data were commended by giving in the form of tables. The results were handed by evaluating the answers given by the participants about their monthly incomes, yearly fish consumption, fish supplying way, fish prices, the kinds of consumed fish, fish cooking form and the seasonal changing of fish consumption. According to results of the study, while people aged less than 21 years consume $60 \%$ of their annual fish consumption during the summer months, this rate was determined as $31.1 \%$ for people aged between 21 and 30 . It was understood that while $29.8 \%$ of the participants whose incomes were lower than 300 Turkish Liras (TRY) consumed fish once a month, this rate was $54.3 \%$ for the participants whose income levels were more than 1200 TRY. While $41.7 \%$ of the participants whose income levels were between 900-1200 TRY were cooking fish by frying method, for the other participants whose income levels were more than $1200 \mathrm{TRY}$ this rate was $62.9 \%$.
\end{abstract}

Please cite this paper as follows:

Arslan, G. (2019). Determination of Fish Consuming Habits of Vocational School Students from Different Families. Marine Science and Technology

Bulletin, 8(2): 40-45.

\section{Introduction}

It has been thought that nutrition and food shortage will be one of the most important problems of rapidly growing human population. The experts have often explained that the food production and producing will increase twice because of increasing population in 2050. For that reason, aquaculture and fisheries are of great importance (Arslan, 2017).

Nowadays, there are nearly 186,000 different marine and freshwater species all over the world that the majority of them are fishes $(21,000$ species $)$ and invertebrates $(16,000$ species $)$ Approximately, five hundred species taking place in mankind's nutrition that the majority of them are also fishes (275-300 species) (Dağtekin and Ak, 2007). Turkey is an important country in terms of aquaculture production potential. In 2016, a totally $170,995,437$ tons of fishery products were produced by fisheries and aquaculture (FAO, 2016). This kind of production activity was nearly 588,725 tons in 2016 in Turkey (TurkStat, 2019).

While global fish consumption per capita is about $20.5 \mathrm{~kg}$ (FAO, 2017), this is about $5.5 \mathrm{~kg}$ in Turkey (TurkStat, 2019), which is

\footnotetext{
* Corresponding author

E-mail address: gokhan.arslan@atauni.edu.tr (G. Arslan)
} 
especially very low in Eastern Anatolia, Southeastern Anatolia and Central Anatolia regions. However, it is quite high in the coastal regions of Turkey (Dağtekin and $\mathrm{Ak}, 2007$ ). In such a way that the annual fish consumption per capita in the Eastern Black Sea Region is about 20-25 kg, while it is extremely low in Eastern and Southeastern Anatolia (Altay et al., 2000). This situation is caused by many factors such as the lack of adequate introductions of fish in the non-coastal cities (positive relationship between human health and fish consumption, etc.), transportation to the hinterlands with higher coast inability to supply freshly consumed aquaculture in all seasons, food habits, variability in prices and income level (Arık Çolakoğlu et al., 2006; Balık et al., 2013).

Indefinite areas in Turkey, many kind of researches intended for fish consumption have been done, and various results have been obtained by evaluating the distance of the region to the sea, the number of fish farms, the income level of the local people, and their education levels. In the present study, the factors affecting the fish consumption and its affective variables of the students educated in Narman country of Erzurum city having a high altitude and to be 230 kilometers far from the sea coast and 90 kilometers far from the city center were evaluated.

\section{Material and Methods}

The study was conducted with a face to face question and answer format with 269 participants, 137 of whom were randomly selected and 132 were men.

The main material of this study consists of gathering the answers to the various questions related to the amount of consumption of aquacultural resources and the causes affecting this amount by making face to face meetings with the students who educate in Narman county of Erzurum city and evaluating them.

The questions as socio-economic status, habits of consumption of aquacultural products, type of consumed fish, amount of consumption, the ways they acquire the fish, causes of their preferences and the baking ways of the participants were asked. The answers were analyzed with the test of Chi-square independence test.

\section{Results}

Survey data related the socio-economic and demographic features, consumption habits by season, consumer's opinions about price, frequency of consumers consumption fish, fish consumption habits, consumption rate of consumers, types of seafood consumption determined from the present study are presented in Table 1-8.

The questionnaire was applied to randomly chosen 269 students and $50.9 \%$ of the participants were female (137 people) and $49.1 \%$ of them were male (132 people) (Table 1). When the number of people in each students' family was inquired, it was understood that they live in such families that $52 \%$ of them had 0-5 family members (totally 140 ), $48 \%$ of them had more than 5 family members (totally 129). It was understood that the $72.5 \%$ of participant students were under 21 years of age, $27.5 \%$ of them were between $21-30$ years of age. In addition, when considering the income level which is one of the factors importantly affecting the people's fish consumptions, $34.3 \%$ of students had 301-600 Turkish Liras (TRY) income. On the other hand, some other participants with the rate of $31.2 \%$ who have 300 TRY of income were following them and the rate of the participant students who had the highest income level was $8.9 \%$ and they had 901-1200 TRY of income levels. When it was looked at the students' residences, $76.6 \%$ of them were living in different places without Erzurum and 23.4\% of them were living in Erzurum city. When it was looked at the fish consumption of the students living in Erzurum, preferred red meat (55.6\%), the students living in different cities without Erzurum mostly preferred white meat $(58.7 \%)$.

Table 1. The socio-economic and demographic features of participants

\begin{tabular}{lc}
\hline \multicolumn{1}{c}{$\mathbf{N = 2 6 9}$} & (\%) \\
\hline Male & 50.9 \\
Female & 49.1 \\
\hline Family members & \\
\hline $0-5$ & 52.0 \\
$>5$ & 48.0 \\
\hline Age & \\
\hline$<21$ & 72.5 \\
$21-30$ & 27.5 \\
\hline Income level (TRY) & \\
\hline$<300$ & 31.2 \\
$301-600$ & 34.2 \\
$601-900$ & 12.6 \\
$901-1200$ & 8.9 \\
$>1200$ & 13.0 \\
\hline Residence & \\
\hline Erzurum & 23.4 \\
Non-Erzurum & 76.6 \\
\hline
\end{tabular}

It was understood that there was a statistically significant difference as a result of the Chi-square independence test $(\mathrm{p}<0.05)$ among the numbers of family members because of the answers given to the question of "How do you find the fish prices?" While 55\% of participants (71 persons) who had 5 or more family members found fish prices expensive, this rate was $37.9 \%$ (53 participants) for the participants having 5 or lower members in their families (Table 2).

As a result of Chi-square independence test applied to determine whether there is a meaningful difference between the ages in terms of answers given to the question of "In which season do you consume more water products?", a significant difference emerged $(\mathrm{p}<0.05)$. While people aged less than 21 years consume $60 \%$ of their annual fish consumption (117 people) during the summer months, this rate was determined as $31.1 \%$ for people aged between 21 and 30 (Table 3).

Chi-square independence test, which was applied to define if there was a difference on account of given answers to the question of "How often do you consume fish?", revealed that there was an important difference $(\mathrm{p}<0.05)$. As a result, it was understood that while $29.8 \%$ of the participants (25 persons) whose incomes were lower than 300 TRY consumed fish once a month, this rate was $54.3 \%$ (19 persons) for the participants whose income levels were more than 1200 TRY. 
Table 2. Opinions about fish price of participants from different family members $(\mathrm{N}=269)$

\begin{tabular}{lcccc}
\hline \multirow{2}{*}{ Number of family members } & \multicolumn{4}{c}{ Opinion about fish prices (\%) } \\
\cline { 2 - 5 } & Inexpensive & Reasonable & Expensive & No idea \\
\hline $0-5(\mathrm{~N}=140)$ & 1.49 & 15.61 & 19.70 & 15.24 \\
$>5$ & 0.00 & 8.18 & 26.39 & 13.38 \\
\hline
\end{tabular}

Note: Pearson Chi-Square is $12.759(\mathrm{p}<0.05)$

Table 3. Seasonal consumption rate (\%) of participants by age $(\mathrm{N}=269)$

\begin{tabular}{lrrrr}
\hline \multirow{2}{*}{ How old are you? } & \multicolumn{3}{c}{ In which season do you consume fish more? } \\
\cline { 2 - 5 } & Spring & Summer & Autumn & Winter \\
\hline \multirow{2}{*}{21} & 5 & 117 & 8 & 65 \\
$21-30$ & 2.6 & 60.0 & $4.1 \%$ & 33.3 \\
& 3 & 23 & 5 & 43 \\
\hline Overall & 4.1 & 31.1 & 6.8 & 58.1 \\
\hline
\end{tabular}

Note: Pearson Chi-Square is $18.003(\mathrm{p}<0.05)$

Table 4. Frequency of fish consumption rate (\%) of participant by income levels ( $\mathrm{N}=269)$

\begin{tabular}{lcccccc}
\hline What is your income & \multicolumn{5}{c}{ How often do you consume fish? } \\
\cline { 2 - 6 } \multicolumn{1}{c}{ level? (TRY) } & Once a week & Once in fifteen days & Once a month & Once a year & I don't consume & N \\
\cline { 2 - 6 }$<300$ & 3.6 & 13.1 & 29.8 & 29.8 & 23.8 & 84 \\
$300-600$ & 7,6 & 12.0 & 44.6 & 17.4 & 18.5 & 92 \\
$600-900$ & 5.9 & 14.7 & 35.3 & 23.5 & 20.6 & 34 \\
$900-1200$ & 8.3 & 0.0 & 54.2 & 16.7 & 20.8 & 24 \\
$>1200$ & 17.1 & 20.0 & 54.3 & 8.6 & 0.0 & 35 \\
\hline Overall & 7.43 & 12.63 & 40.89 & 20.81 & 18.21 & 269 \\
\hline
\end{tabular}

Note: Pearson Chi-Square is $31.242(\mathrm{p}<0.05)$

Table 5. Fish consumption rate (\%) amounts of participant by income levels $(\mathrm{N}=269)$

\begin{tabular}{llcccc}
\hline \multirow{2}{*}{ What is your income level? (TRY) } & \multicolumn{4}{c}{ How much amount of seafood are you consuming monthly? } & \multirow{2}{*}{$\mathbf{N}$} \\
\cline { 2 - 5 } & $\mathbf{1 - 3} \mathbf{~ k g}$ & $\mathbf{4 - 6} \mathbf{~ k g}$ & $\mathbf{6 - 1 0 ~ \mathbf { ~ k }}$ & $\mathbf{1 0} \mathbf{~ k g}$ & \\
\hline$<300$ & 50.0 & 25.0 & 10.7 & 14.3 & 84 \\
$300-600$ & 44.6 & 28.3 & 17.4 & 9.8 & 92 \\
$600-900$ & 52.9 & 17.6 & 11.8 & 17.6 & 34 \\
$900-1200$ & 20.8 & 12.5 & 25.0 & 41.7 & 24 \\
$>1200$ & 40.0 & 14.3 & 22.9 & 22.9 & 35 \\
\hline Overall & 44.6 & 22.7 & 15.9 & 16.8 & 269 \\
\hline
\end{tabular}

Note: Pearson Chi-Square is $25.196(\mathrm{p}<0.05)$

Table 6. Season consumption rate (\%) of participant by income levels (N=269)

\begin{tabular}{lccccc}
\hline \multirow{2}{*}{ What is your income level? (TRY) } & \multicolumn{4}{c}{ In which season do you consume more water product? } & \multirow{2}{*}{ N } \\
\cline { 2 - 5 } & Spring & Summer & Autumn & Winter & \\
\hline$<300$ & 1.2 & 58.3 & 0.0 & 40.5 & 84 \\
$300-600$ & 5.4 & 40.2 & 12.0 & 42.4 & 92 \\
$600-900$ & 0.0 & 44.1 & 5.9 & 50.0 & 34 \\
$900-1200$ & 8.3 & 70.8 & 0.0 & 20.8 & 24 \\
$>1200$ & 0.0 & 62.9 & 0.0 & 37.1 & 35 \\
\hline Overall & 3.0 & 52.0 & 4.9 & 40.1 & 269 \\
\hline
\end{tabular}

Note: Pearson Chi-Square is $32.975(\mathrm{p}<0.05)$ 
The answers given with regard to the question of "How much amount of seafood are you consuming monthly?" with the purpose of determining if there was a difference among the level of income by applying the results of Chi-square independence test, the results showed that there was a significant difference $(\mathrm{p}<0.05)$. While the participant students whose income levels were between 600-900 TRY consumed $1-3 \mathrm{~kg}$ of fish in a month and their percentage was $52.9 \%$ (18 persons) the other participant students whose income levels were between 900-1200 TRY, their percentage rate was $20.8 \%$ (5 persons) (Table 5).

Table 6 presents the answers given with regard to the question of "In which season do you consume more water products?" with the purpose of determining if there was a difference among the level of income by applying the results of Chi-square independence test and its results showed that there was a significant difference $(\mathrm{p}<0.05)$. While $50 \%$ (17 people) of people with/while income level between 600-900 TRY consumed more fish during the winter months, this rate was determined as $20.8 \%$ (5 people) of people with/having income levels between 900 and 1200 TRY.

In Table, the answers given by the participant students to the question of "What is your fish cooking method?" were presented and the Chi-square independence test used to understand if there was a significant difference. As a result of the test, it was understood that there was a significant difference among them $(\mathrm{p}<0.05)$. While $41.7 \%$ of the participants whose income levels were between 900-1200 TRY
(10 persons) were cooking fish by frying method, for the other participants whose income levels were more than 1200 TRY this rate was $62.9 \%$ (22 persons) (Table 7).

With the aim of understanding if there was a significant difference among the participant students living in Erzurum the Chi-square independence test was employed. As a result of this test, it was understood that there was a significant difference $(\mathrm{p}<0.05)$. While $55.6 \%$ of the participants living in Erzurum (35 persons) were consuming red meat more, this rate for the participant students living in different cities was $30.1 \%$ (62 persons) (Table 8).

Table 9 presents the answers given by the participant students to the question of "Where do you buy fish?" the Chi square independence test was used to understand if there was a significant difference. As a result of the test, it was understood that there was a significant difference among them $(\mathrm{p}<0.05)$. It is declared that while $66.7 \%$ of the participants (42 persons) living in Erzurum define that they buy fish from market places, the rate for the other participant students living in some different countries was $49.5 \%$ (102 persons).

As it can be seen in Table 9, the market places have a very important place in the access to finish regardless of where they live. Because fish is a highly perishable foodstuff, the cold chain is of vital importance to its transport and storage. Buying fish from fish market brings many health risks that can be caused by cold chain breaks. Therefore, consumers should be aware of this issue.

Table 7. Consumption rate (\%) of participant by income levels

\begin{tabular}{|c|c|c|c|c|c|}
\hline \multirow{2}{*}{ What is your income level? (TRY) } & \multicolumn{4}{|c|}{ What is your fish cooking method? } & \multirow{2}{*}{$\mathbf{N}$} \\
\hline & Fried & Grilled & Steamed & Others & \\
\hline$<300$ & 71.4 & 6.0 & 9.5 & 13.1 & 84 \\
\hline $300-600$ & 59.8 & 23.9 & 10.9 & 5.4 & 92 \\
\hline $600-900$ & 41.2 & 17.6 & 17.6 & 23.5 & 34 \\
\hline $900-1200$ & 41.7 & 25.0 & 16.7 & 16.7 & 24 \\
\hline$>1200$ & 62.9 & 28.6 & 5.7 & 2.9 & 35 \\
\hline Overall & 59.9 & 18.2 & 11.2 & 10.7 & 269 \\
\hline
\end{tabular}

Note: Pearson Chi-Square is $32.975(\mathrm{p}<0.05)$

Table 8. Types of seafood consumption rate (\%) of participant

\begin{tabular}{lrrrrr}
\hline \multirow{2}{*}{ Do you live in Erzurum? } & \multicolumn{3}{c}{ Which type of meat do you consume more? } & \multirow{2}{*}{ N } \\
\cline { 2 - 5 } & \multicolumn{1}{c}{ Fish } & Red meat & White meat & 63 \\
Yes & 4.8 & 55.6 & 39.7 & 58.7 & 206 \\
No & 11.2 & 30.1 & 54.2 & 269 \\
\hline Overall & 9.7 & 36.1 & & \\
\hline
\end{tabular}

Note: Pearson Chi-Square is $13.946(\mathrm{p}<0.05)$

Table 9. Where fisheries are supplied of participant (\%)

\begin{tabular}{lrrrrr}
\hline \multirow{2}{*}{ Do you live in Erzurum? } & \multicolumn{3}{c}{ Where do you buy fish? } & \multirow{2}{*}{ N } \\
\cline { 2 - 5 } & Market Place & Fish Sales Room & Fish Market & Peddler & 63 \\
\hline Yes & 66.7 & 11.1 & 9.5 & 12.7 & 20 \\
No & 102 & 53 & 31 & 206 \\
\hline Overall & 53.5 & 22.3 & 13.8 & 10.4 & 269 \\
\hline
\end{tabular}

Note: Pearson Chi-Square is $8.758(\mathrm{p}<0.05)$ 


\section{Discussion and Conclusion}

Many studies that emerged in recent years had focused on the positive effects of n-3 polyunsaturated fatty acids on human health (principally eicosapentaenoic acid and docosahexaenoic acid) (Montaño et al., 2001; Moyad, 2005; Wertz, 2009; Sekikawa et al., 2015; Bellenger et al., 2019). United Kingdom Scientific Advisory Committee on Nutrition (UK SACN, 2004) has reported that almost 300 grams of fish should be consumed per person per week for a healthy life. In Turkey, the fish consumption of per person is both very low and constitutes a significant part of a single species (European anchovy, Engraulis encrasicolus, captured from the Black Sea). Therefore, in addition to increasing of the amount of fish consumption per person to have a healthier society, other species should be included in the balance of consumption depending on the only one species. This situation may enlighten the consumer choice in Turkey. The social and state campaigns treated on the effects of fish meat on human health and consumer choice can be gathered on fish meat. At these campaigns, the first target must be the high-income level. Then, with the control of fish prices, this situation should be also reflected in lower income levels.

According to fish consumption of the students living in Erzurum, they preferred red meat (55.6\%), the students living in different cities without Erzurum mostly preferred white meat (58.7\%). The least consumed meat type is fish meat without depending on where they live. In the study of Oğuzhan et al. (2009) with the aim of defining the consuming habits of aquaculture products, it was defined that the people liked to consume red meat the most (56\%), seconded by chicken $(37.3 \%)$ and fish (6.7\%). For that reason, our results show similarities with the findings of Oguzhan et al. (2009). The most important factors in food consumption are cultural effects, income level and consumer awareness. Turkey's people pay no attention to the fish consumption even if they have financial possibilities. As a result of this study, more emphasis should be made to create social awareness on the positive relationship between fish consumption and human health and the mean fish consuming amount of Turkey (5.6 kg/year) must be increased to higher levels.

The questionnaires are important data resources to have information and estimation about any subject. In this study, the university students educated in Narman county of Erzurum city were asked questions about the fish consumption and the answers given by them were evaluated by using suitable statistical methods. At the end of this study with the aim of evaluating the university students' fish consuming habits following general results were acquired:

- While some of the participant students (some of the people) at the ages of under 21 were carrying out their fish consumption's $60 \%$ in summer months, it was found out that this rate was nearly $31 \%$ for the remainder of the students whose ages were between 21 and 30. This situation showed that the more the consumers' ages increased the more the consciousness increased equally and a result of this position it was understood that the fish consumption spread over the whole year.

- As income level increases, fish consumption frequently increases. This means that approximately $30 \%$ of people with income level less than 300 TRY consume fish once a month, while those with income levels more than $1200 \mathrm{TRY}$ have reacted $54 \%$. As an even more interesting result is the fact that $63 \%$ of the group representing the upper-income level has the highest fish consumption in Turkey cause to the production of raw materials during the summer season. Fish consumption frequently increases by about two times as much as income level increases by four times. In addition, there is no one consuming fish at the upper-income level, while the lowest income class is about $24 \%$. This result shows that people do not care much about the content of the food they consume, whereas the benefits of the food consumed with economic prosperity are important in terms of health regardless of the price.

- It was defined that $66.7 \%$ and $45.8 \%$ of the groups having income levels of 900-1200 TRY and 1200+ TRY consumed 6 kilograms fish per year, respectively. Also, it was defined that the fish consumption amount was increasing with the rise of income level being in a harmony with the frequency of fish consumption. For that reason as the income level increased, either the consumer's consciousness of awareness increased or the price did not have importance to become an obstacle to reach healthy food.

- The most interesting results of this study are the monthly distributions of fish consumption. Specifically, nearly $63 \%$ of the participants symbolizing the upper level of income consume fish in summer months in which fish consumption is minimum in Turkey because of the product depending on the European anchovy. Also, it was found out that the groups nearly did not consume fish in spring and autumn. The most caught fish in Turkey is the anchovy, which constitutes 59\% of Turkey's total fisheries production in 2017 (TurkStat, 2019). While it is an expected result for the fish consumption to increase in winter months due to the catching of anchovies in the middle of autumn and winter months, it is unexpected result for the consumption of it to be lower in the autumn. This situation may be a unique situation for the students since students that tend to live with their families are fed healthier. But, it is also clear that this study could not give data about the general fish consumption of Turkey.

- It was found out that there was a difference between the fish cooking methods and income. According to the study the people who had low income levels preferred more practical methods. This difference between income level and fish cooking options was due to the costs of fish cooking. People who had low incomes prefer cooking options of less cost. The fish cooking options are related to fish preferences and the climate. Fish cooking option is used more by frying method since the average annual air temperature is low.

- The fish markets have a great importance for the people to reach the fish where they are located. The cold chain has crucial importance for transporting and keeping it fresh because of it going deforming easily. There are many health risks of fish buying from market places because of breaking the cold chain. For that reason, the consumers should be informed and awareness should be raised absolutely.

\section{Conflict of Interest}

The author declares that there is no conflict of interest. 


\section{References}

Arık Çolakoğlu, F., İşmen, A., Özen, Ö., Çakır, F., Yı̆̆ın, Ç. \& Ormancı, H. B. (2006). Çanakkale İlindeki Su Ürünleri Tüketim Davranışlarının Değerlendirilmesi. Ege Üniversitesi Su Ürünleri Dergisi, 23(Ek 1/3): 387-392.

Arslan, G. (2017). Gökkuşağı Alabalığı (Oncorhynchus mykiss) Yavru Yemlerine Farklı Oranlarda İlave Edilen Üzüm Çekirdeği Yağının (Vitis vinifera) Büyüme, Yaşama Gücü, Yağ Asidi Profili, Antioksidan Enzim Düzeyleri ve Kan Parametreleri Üzerine Etkisi. Ph.D. Thesis. Atatürk University, Erzurum, Turkey.

Altay, D., Ölmez, M. \& Korkmaz, A. Ş. (2000). Su Ürünleri Üretimi. TMMOB Ziraat Mühendisleri Odası Türkiye Ziraat Mühendisliği 5. Teknik Kongresi, 2: 827-843.

Balık, İ., Yardımcı, C. \& Turhan, O. (2013). Ordu İli Fatsa ve Aybastı İlçelerinde Balık Tüketim Alışkanlıklarının Karşılaştırmalı Olarak İncelenmesi. Ordu Üniversitesi Bilim ve Teknoloji Dergisi, 3(2): 18-28.

Bellenger, J., Bellenger, S., Escoula, Q., Bidu, C. \& Narce, M. (2019). N3 polyunsaturated fatty acids: An innovative strategy against obesity and related metabolic disorders, intestinal alteration and gut microbiota dysbiosis. Biochimie, 159: 66-71.

Dağtekin, M. \& Ak, O. (2007). Doğu Karadeniz Bölgesinde Su Ürünleri Tüketimi, İhracat ve İthalat Potansiyeli. SÜMAE Yunus Araştırma Bülteni, 7(3): 14-17.

FAO. (2016). The State of World Fisheries and Aquaculture. Food and Agriculture Organization of the United Nations. 223 p, Rome, Italy.
FAO. (2017). Fishery Statistics. Food and Agriculture Organization. Retrieved on August 5, 2019 from http://www.fao.org/fishery/statistics/software/fishstatj/en

Moyad, M. A. (2005). An introduction to dietary/supplemental omega-3 fatty acids for general health and prevention: Part II. Urologic Oncology: Seminars and Original Investigations, 23(1): 36-48.

Montaño, N., Gavino, G. \& Gavino, V. C. (2001). Polyunsaturated fatty acid contents of some traditional fish and shrimp paste condiments of the Philippines. Food Chemistry, 75: 155-158.

Oğuzhan, P., Angiş, S. \& Atamanalp, M. (2009). Erzurum İlindeki tüketicilerin su ürünleri tüketim alışkanlığının belirlenmesi üzerine bir araştırma. XV. Ulusal Su Ürünleri Sempozyumu, Rize, Turkey.

Sekikawa, A., Doyle, M. F. \& Kuller, L. H. (2015). Recent findings of long-chain n-3 polyunsaturated fatty acids (LC n-3 PUFAs) on atherosclerosis and coronary heart disease (CHD) contrasting studies in Western countries to Japan. Trends in Cardivascular Medicine, 25: 717-723.

TurkStat. (2019). Fishery Statistics. Turkish Statistical Institute. Retrieved on August 3, 2019 from http://www.tuik.gov.tr/PreTablo.do?alt_id=1005

UK SACN, (2004). Advice on fish consumption: Benefits \& risks. Retrieved on August 3, 2019 from https://cot.food.gov.uk/sites/default/files/cot/fishreport200 401.pdf

Wertz, P.W. (2009). Essential fatty acids and dietary stress. Toxicology and Industrial Health, 25: 279-283. 